\title{
R\&D Spillover Effects on the Strategic Behavior of Large International Firms during the World Financial Crisis
}

\author{
Luigi Aldieri ${ }^{1}$, Maria Carmela Aprile ${ }^{2} \&$ Concetto Paolo Vinci $^{3}$ \\ ${ }^{1}$ Department of Business and Economic Studies, Parthenope University of Naples, Naples, Italy \\ ${ }^{2}$ Department of Economic and Legal Studies, Parthenope University of Naples, Naples, Italy \\ ${ }^{3}$ Department of Economic and Statistical Sciences, University of Salerno, Fisciano, Italy \\ Correspondence: Luigi Aldieri, Department of Business and Economic Studies, Parthenope University of Naples, \\ Naples, Italy, Via Generale Parisi, 13, 80132 Naples, Italy. E-mail: aldieri@uniparthenope.it
}

Received: August 11, 2017

doi:10.5539/ijbm.v12n11p141
Accepted: September 21, 2017

Online Published: October 18, 2017

URL: https://doi.org/10.5539/ijbm.v12n11p141

\begin{abstract}
The aim of this study is to investigate the relationship between competition and innovation through the knowledge spillover effect. In particular, we investigate whether R\&D competition is sensitive to economic shock. To this end, we consider a period of time related also to the 2008 financial crisis. We implement an empirical analysis of 879 worldwide R\&D-intensive firms. In order to measure technological proximity, we use two approaches: one based on Jaffe industry weight matrix, relative to patents distributed across technology classes; one based on trade intensity between sectors using input-output matrix data. The empirical results show a positive effect of R\&D externalities on competitive interactions before the beginning of crisis and a negative one after it. These findings are robust with respect to the procedure employed in the estimation method.
\end{abstract}

Keywords: panel data models, innovation, R\&D spillovers

JEL codes: C33; O32; O33

\section{Introduction}

This paper aims to examine the relation between R\&D competitions on firm's own R\&D efforts. The analysis covers the period 2002-2010 and it is performed in two stages.

With respect to the existing literature, our study provides a twofold contribution: on the one hand, we investigate whether R\&D competition is sensitive to financial shocks. To this end, we split our sample into two periods, one before the beginning of the crisis (2002-2006), and one after it (2007-2010). On the other hand, we also explore the competition effect by implementing an alternative empirical procedure based on trade intensity between sectors using input-output matrix data (Timmer, Dietzenbacher, Los, Stehrer \& de Vries., 2015).

The paper is organized as follows. Section 2 outlines the relevant literature about competition and innovation. Section 3 details the data. In section 4, the statistical analysis is discussed, and finally section 5 proposes a discussion of policy implications.

\section{Literature Review}

We may identify in the literature various works on the relationship between competition and innovation. Several empirical studies have analyzed the effects of research and development (R\&D) decisions taken by a firm on the $R \& D$ choices of competitors. The first empirical studies that analyzed interaction between R\&D investments and competition is Scherer (1967), which discovered an inverted U shape, with higher competition initially increasing then reducing the rate of innovation. In particular, the author showed a positive relationship between patenting activity and firm size in the cross section, with a diminishing impact at larger sizes when allowing for nonlinearities. Nickell (1996) and Blundell, Griffith and Van Reenen (1999) both find a positive linear effect of competition on innovation. Further studies, which focus on technological strategic interactions, converge to determine significant competitive interaction patterns regarding R\&D behavior (Capron \& Cincera, 2001). Scherer (1992) and Scherer and Huh (1992) analyzed US firms' R\&D reactions to competition from foreign firms. Their results suggest that international firms reacted more aggressively than American ones. Capron (1994) investigated competition in three different economic areas. The results obtained indicated a typical behavior in 
leadership regarding US firms. Capron and Cincera (2001) explored the strategic relationship between R\&D externalities and productivity at the firm level. The estimates showed that the competitive behaviors are not homogeneous. Recent studies have focused on the effects caused by the economic crisis on firms' decisions concerning innovation. Filippetti and Archibugi (2011) explored empirically the effects of the 2008 economic crisis on innovation across European countries. They found that a substantial number of firms have managed to maintain their investments in innovation, but the number of firms able to expand investments has dropped, and the firms that have decreased such investments have also increased them. However, this trend is not distributed uniformly across the European economic space. The most affected countries are the new member states of Central and Eastern Europe. Some structural factors may explain the effect of the economic downturn on the innovation investments of firms. Among others, there are the competences and quality of human resources, the degree of specialization in the high technology sector, and the development of the financial system. Paunov (2012) analyzed the impact of the 2008-2009 global crisis on firms' innovation profiles by exploring original firm-level data for eight Latin American countries. The results of the analysis showed that rising financing constraints and the negative demand shock due to the economic crisis had an impact on firms' decisions to abandon innovation projects. Specifically, the probit regression results indicated that firms with access to public funding were less likely to abandon investments in innovation projects. This has been found with reference to younger firms and foreign multinationals suffering export shocks. Archibugi, Filippetti and Frenz (2013a) investigated whether the 2008 financial crisis affected the composition of innovating firms in the EU-27 member states plus Norway and Switzerland. Applying the Shumpeterian hypotheses of creative destruction and technological accumulation, the analysis compares drivers of innovation investment before, during, and following from the crisis. The empirical results highlight that in periods of economic expansion, firms that are already innovating are the most important drivers of increased innovation investment, supporting the technological accumulation hypothesis. However, during the crisis, a decline in technological opportunities in established sectors took place. Thus, both formal R\&D and technological opportunities ceased playing a significant role in explaining companies' willingness to expand innovation. Contrary to the previous period, newcomers were eager to spend more to innovate. That is, innovation was driven by fresh opportunities in new markets. In a further study, Archibugi et al. (2013b) investigated how the 2008 economic downturn affected different typologies of UK innovating firms. The authors found that the crisis led to a concentration of innovative activities within a small group of fast growing new firms and those firms already highly innovative before the crisis. The companies in pursuit of more explorative strategies toward new product and market developments were those that coped better with the crisis.

\section{Data and Variables}

The dataset is the same as in Aldieri and Vinci (2015, 2016 and 2017). The information on company profiles and financial statements comes from all 2011 by the JRC-IPTS scoreboards (European Commission, 2011). The OECD REGPAT database, January 2012, is the second source of information used in this study. This database covers firms' patent applications to the European Patent Office (EPO), including patents published up to December 2011. The dataset covers regional information for most OECD and EU-27 countries, plus Brazil, Russia, India, China, and South Africa (BRICS countries).

The matching between the firms in the R\&D scoreboard and their counterpart in OECD, the REGPAT database, January 2012, is not straightforward and involves the same difficulties as in Aldieri and Vinci (2015, 2016 and 2017). The R\&D and physical capital stocks (K and C, respectively) are constructed using a perpetual inventory method (Griliches, 1979), employing a depreciation rate of 0.15 for R\&D capital stock and 0.08 for physical capital stock, as usually assumed in the literature. As the GDP price deflator deflates sales, R\&D, and physical expenditures, and we use the same depreciation rate independently of the industry to which the firm belongs, this could lead to measurement bias, which should be considered in the empirical findings. The growth rates used for the initial values in this study are the sample average growth rates of R\&D and physical capital expenditures in each two-digit ICB industry. This leads to an unbalanced panel of 879 firms.

To measure the pool of external knowledge, we follow the methodology developed by Jaffe (1986): technological proximities between firms are given as the uncentered correlation coefficients between the corresponding technology vectors:

$$
P_{i j}=\frac{\sum_{z=1}^{Z} T_{i z} T_{j z}}{\sqrt{\sum_{z=1}^{Z} T_{i z}^{2} \sum_{z=1}^{Z} T_{j z}^{2}}}
$$

where $T_{i}$ is the technological vector of firm $i$ and $P_{i j}$ is the technological proximity between firm $i$ and $j$. Based on this procedure, the total weighted stock of $\mathrm{R} \& \mathrm{D}$ spillovers is computed as follows: 


$$
T S_{i}=\sum_{i \neq j} P_{i j} K_{j}
$$

Where $K_{j}$ is the R\&D capital stock of firm $j$. However, this technological proximity index exhibits some relevant drawbacks, as emphasized by Jaffe (1986). For this reason, the results detected from its application should be interpreted with caution.

Table 1 presents the Herfindhal index $(\mathrm{H})$ for each industry. These measures have been estimated on the basis of the 879 firms' patent distributions across 50 classes and over the period 2002-2010'. The last row indicates that technological activities are more concentrated in financial intermediation (banking) industry $(\mathrm{H}=0.86)$, travel and leisure $(\mathrm{H}=0.52)$, retail trade in food and drugs (retail) $(\mathrm{H}=0.34)$ and post and telecommunication (post) $(\mathrm{H}=0.26)$, while the firms in other industries seem to show diversified technological activities.

Table 1. Technological proximities within and across industries (firm averages)

\begin{tabular}{llllllllllllllll}
\hline & $\mathbf{5}$ & $\mathbf{1 3}$ & $\mathbf{1 7}$ & $\mathbf{2 3}$ & $\mathbf{2 7}$ & $\mathbf{3 3}$ & $\mathbf{3 5}$ & $\mathbf{3 7}$ & $\mathbf{4 5}$ & $\mathbf{5 3}$ & $\mathbf{5 5}$ & $\mathbf{6 5}$ & $\mathbf{7 5}$ & $\mathbf{8 3}$ & $\mathbf{9 5}$ \\
\hline Oil \& gas & 0.18 & & & & & & & & & & & & & \\
Chemicals & 0.18 & 0.21 & & & & & & & & & & & & \\
Basic resources & 0.22 & 0.28 & 0.18 & & & & & & & & & & & \\
Construction & 0.2 & 0.25 & 0.19 & 0.19 & & & & & & & & & & \\
Industrial goods and services & 0.22 & 0.26 & 0.19 & 0.21 & 0.32 & & & & & & & & & \\
Automobiles & 0.24 & 0.27 & 0.22 & 0.23 & 0.27 & 0.26 & & & & & & & & \\
Food \& beverages & 0.22 & 0.28 & 0.23 & 0.23 & 0.24 & 0.23 & 0.23 & & & & & & & \\
Household goods & 0.23 & 0.3 & 0.2 & 0.21 & 0.23 & 0.24 & 0.19 & 0.25 & & & & & & \\
Health care & 0.24 & 0.31 & 0.22 & 0.22 & 0.24 & 0.21 & 0.21 & 0.25 & 0.28 & & & & & \\
Retail & 0.16 & 0.22 & 0.16 & 0.17 & 0.21 & 0.15 & 0.26 & 0.29 & 0.41 & 0.27 & & & & \\
Travel \& leisure & 0.19 & 0.09 & 0.16 & 0.18 & 0.34 & 0.46 & 0.06 & 0.16 & 0.11 & 0.1 & 0.19 & & & \\
Post & 0.26 & 0.31 & 0.22 & 0.23 & 0.28 & 0.3 & 0.16 & 0.25 & 0.22 & 0.18 & 0.38 & 0.26 & & \\
Utilities & 0.24 & 0.28 & 0.25 & 0.23 & 0.27 & 0.3 & 0.16 & 0.23 & 0.25 & 0.14 & 0.26 & 0.14 & 0.31 & \\
Banking & 0.15 & 0.14 & 0.17 & 0.18 & 0.26 & 0.17 & 0.12 & 0.23 & 0.18 & 0.3 & 0.33 & 0.32 & 0.27 & 0.32 \\
Technology & 0.23 & 0.28 & 0.22 & 0.23 & 0.26 & 0.26 & 0.18 & 0.24 & 0.26 & 0.18 & 0.32 & 0.21 & 0.31 & 0.16 & 0.25 \\
\hline Herfindhal index & 0.15 & 0.06 & 0.12 & 0.13 & 0.03 & 0.04 & 0.12 & 0.08 & 0.04 & 0.34 & 0.52 & 0.26 & 0.15 & 0.86 & 0.05 \\
\hline
\end{tabular}

Note: row name indicates ICB sector and column name represents the two-digit ICB code.

\section{Empirical Framework}

\subsection{Model Specification}

In order to investigate the impact of $R \& D$ technological spillovers on competitive interactions, we consider the following specification model:

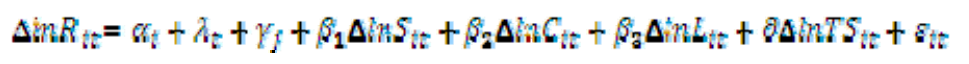

Where $\ln$ = natural logarithm;

$\Delta=$ first-difference operator;

$S_{i t}=$ net sales for firm $i$ and year $\mathrm{t}$;

$C_{i t}=$ physical capital stock for firm $i$ and year $t$

$L_{i t}=$ number of employees for firm $i$ and year $t$;

$R_{i t}=$ annual R\&D expenditures of firm $i$ and year $t$;

$\alpha_{i}=$ firm's fixed effects;

$\lambda_{t}=$ set of time dummies;

$\gamma_{j}=$ set of country dummies; 
$T S_{i t}=$ vector of total stock of spillover components for firm $i$ and year $t$;

$\beta, \delta, \gamma=$ vectors of parameters;

$\varepsilon_{i t}=$ disturbance term.

We can expect two possible effects of spillovers on own R\&D activity. On the one hand, imperfect technological appropriability reduces the incentive to invest in $R \& D$, but on the other hand, the oligopolistic context of the markets in which the firms operate should make them more R\&D intensive. In Table 2, we show the summary statistics of our sample. In particular, we consider both the total stock of spillovers based on the Jaffe procedure and the total stock of spillovers based on the trade based proximity method, relative to the robustness analysis of our empirical findings.

Table 2. Summary statistics

\begin{tabular}{lll}
\hline Variable & Mean $^{\mathrm{a}}$ & Std. Dev. \\
\hline $\ln \mathrm{R}$ & 4.89 & 1.435 \\
$\ln \mathrm{S}$ & 8.02 & 1.643 \\
$\ln \mathrm{C}$ & 7.04 & 1.797 \\
$\ln \mathrm{L}$ & 9.46 & 1.549 \\
$\ln \mathrm{S}^{\mathrm{b}}$ & 12.89 & 0.429 \\
$\operatorname{lnTS}$ & 8.46 & 1.626 \\
\hline
\end{tabular}

Notes: a) 5,853 observations;

b) Jaffe procedure

c) Trade-based proximity procedure

\subsection{GMM Estimation Procedure}

In order to overcome the simultaneity and endogeneity issues, we estimated a one-stage generalized method of moments (GMM) estimator.

In Table 3, we present the empirical estimates for the GMM-SYS estimator. In particular, we explore the extent to which the R\&D competitive effect is sensitive to the world financial crisis. To this end, we split our sample into two periods, one before the beginning of the crisis (2002-2006) and one after it (2007-2010).

Table 3. GMM Jaffe results

\begin{tabular}{|c|c|c|}
\hline \multirow[t]{2}{*}{ Dependent variable: $\Delta \ln \mathrm{Rt}$} & \multicolumn{2}{|c|}{ Sample: $2002-2006$} \\
\hline & Estimate & S.E. ${ }^{a}$ \\
\hline$\Delta \ln S$ & 0.01 & $(0.350)$ \\
\hline$\Delta \operatorname{lnC}$ & $1.09^{*}$ & $(0.646)$ \\
\hline$\Delta \ln L$ & $0.79 * *$ & $(0.403)$ \\
\hline$\Delta \operatorname{lnTS}$ & $5.79 * *$ & $(2.852)$ \\
\hline $\operatorname{AR}(1)^{\mathrm{c}}$ test & $\mathrm{z}=-2.56$ & $\mathrm{p}>\mathrm{z}=0.011$ \\
\hline $\mathrm{AR}(2)$ test & $\mathrm{z}=1.25$ & $\mathrm{p}>\mathrm{z}=0.212$ \\
\hline Hansen $^{\mathrm{b}}: \chi^{2}(9)=4.42$ & & {$[0.882]$} \\
\hline \multirow[t]{3}{*}{ Difference-in-Hansen tests ${ }^{\mathrm{d}}: \chi^{2}(5)=2.11$} & & {$[0.834]$} \\
\hline & \multicolumn{2}{|c|}{ Sample: 2007-2010 } \\
\hline & Estimate & S.E. ${ }^{a}$ \\
\hline$\Delta \ln S$ & $0.35^{* * *}$ & $(0.105)$ \\
\hline$\Delta \ln C$ & $0.35^{* * *}$ & $(0.128)$ \\
\hline$\Delta \operatorname{lnL}$ & 0.04 & \\
\hline
\end{tabular}




\begin{tabular}{lll}
\hline & & $(0.176)$ \\
$\Delta \operatorname{lnTS}$ & $-2.22^{*}$ & $(1.319)$ \\
$\operatorname{AR}(1)^{\mathrm{c}}$ test & $\mathrm{z}=-5.28$ & $\mathrm{p}>\mathrm{z}=0.007$ \\
$\operatorname{AR}(2)$ test & $\mathrm{z}=0.47$ & $\mathrm{p}>\mathrm{z}=0.640$ \\
Hansen $^{\mathrm{b}}: \chi^{2}(41)=36.81$ & & {$[0.657]$} \\
Difference-in-Hansen tests $^{\mathrm{d}}: \chi^{2}(8)=5.28$ & & {$[0.727]$} \\
\hline
\end{tabular}

Notes: a: heteroskedastic-consistent standard errors; b: Hansen test of over-identifying restrictions, p-value in squared brackets; c: $\operatorname{AR}(1)$ and $\operatorname{AR}(2)$ are tests for first- and second-order serial correlation; ***, **, * coefficient significant at the $1 \%, 5 \%, 10 \%$ level respectively. Country, time and industry dummies included. Endogenous variables are sales, physical capital, labor, and R\&D capital stock. Instruments are $1 \mathrm{~s}_{\mathrm{t}-1}, \mathrm{~s}_{\mathrm{t}-2}, \mathrm{l}_{\mathrm{t}-1}$, $1 c_{t-2}, 11_{t-1}, 11_{t-2}$, ltot $_{t-1}$, ltot $_{t-2}$ for both models.

We may observe the complementarity between physical capital and the firm's own R\&D expenditures. The coefficient of technological externalities is significant and positive in the period before the beginning of the crisis. This result is in line with the related literature (Capron and Cincera, 2001). However, as far as the period after the beginning of the crisis is concerned, the coefficient becomes statistically negative. It would be interesting in future research to investigate whether this negative effect is related to the different impact of the crisis on industrial sectors, or the financial constraints of firms.

\subsection{Robustness Analysis}

To test for the robustness of our empirical findings, we employ other industry weights. In previous studies, sector-based trade flow statistics have been used (Carboni, 2013). Morrison and Siegel (1999) distinguish between potential spillovers as being either demand-driven or supply-driven. They assume that the more industry $i$ acquires from and sells to industry $j$, the more it may be affected by industry $j$ (Audretsch \& Feldman, 1996; Peri, 2005). To identify the industry proximity weights, we introduce a matrix based on a measure of trade intensity between sectors derived from the input-output matrix data (Timmer et al., 2015).

In Table 4, we replicate the estimates followed previously to test the robustness of our results.

Table 4. GMM trade proximity results

\begin{tabular}{|c|c|c|}
\hline \multirow[t]{2}{*}{ Dependent variable: $\Delta \ln \mathrm{R}_{\mathrm{t}}$} & \multicolumn{2}{|c|}{ Sample: 2002-2006 } \\
\hline & Estimate & S.E. ${ }^{a}$ \\
\hline$\Delta \ln S$ & -0.51 & $(0.296)$ \\
\hline$\Delta \ln C$ & $1.15^{* *}$ & $(0.563)$ \\
\hline$\Delta \operatorname{lnL}$ & 0.15 & $(1.044)$ \\
\hline$\Delta \operatorname{lnTS}$ & $0.10^{* *}$ & $(0.049)$ \\
\hline $\operatorname{AR}(1)^{\mathrm{c}}$ test & $\mathrm{z}=-2.21$ & $\mathrm{p}>\mathrm{z}=0.027$ \\
\hline $\operatorname{AR}(2)$ test & $\mathrm{z}=1.17$ & $\mathrm{p}>\mathrm{z}=0.242$ \\
\hline Hansen $^{\mathrm{b}}: \chi^{2}(4)=7.49$ & & {$[0.112]$} \\
\hline \multirow[t]{3}{*}{ Difference-in-Hansen tests ${ }^{\mathrm{d}}: \chi^{2}(4)=7.36$} & & {$[0.118]$} \\
\hline & \multicolumn{2}{|c|}{ Sample: $2007-2010$} \\
\hline & Estimate & S.E. ${ }^{a}$ \\
\hline$\Delta \ln S$ & -0.07 & $(0.102)$ \\
\hline$\Delta \ln C$ & 0.14 & $(0.236)$ \\
\hline$\Delta \operatorname{lnL}$ & $1.14^{* * *}$ & \\
\hline
\end{tabular}




\begin{tabular}{lll}
\hline & & $(0.199)$ \\
$\Delta \operatorname{lnTS}$ & $-0.03^{* *}$ & $(0.013)$ \\
$\mathrm{AR}(1)^{\mathrm{c}}$ test & $\mathrm{z}=-5.78$ & $\mathrm{p}>\mathrm{z}=0.000$ \\
$\mathrm{AR}(2)$ test & $\mathrm{z}=0.75$ & $\mathrm{p}>\mathrm{z}=0.453$ \\
Hansen $^{\mathrm{b}}: \chi^{2}(60)=84.94$ & & {$[0.020]$} \\
Difference-in-Hansen tests $^{\mathrm{d}}: \chi^{2}(16)=10.83$ & & {$[0.820]$} \\
\hline
\end{tabular}

Notes: a: heteroskedastic-consistent standard errors; b: Hansen test of over-identifying restrictions, $p$-value is in squared brackets; c: $\operatorname{AR}(1)$ and $\operatorname{AR}(2)$ are tests for first- and second-order serial correlation; ***, **, * coefficients significant at the $1 \%, 5 \%, 10 \%$ levels respectively. Country, time and industry dummies are included. Endogenous variables are sales, physical capital, labor, and R\&D capital stock. Instruments are $1 \mathrm{~s}_{\mathrm{t}-1}, \mathrm{ls}_{\mathrm{t}-2}, \mathrm{c}_{\mathrm{t}-1}$, $1 c_{t-2}, 11_{t-1}, 11_{t-2}$, ltot $_{t-1}, l_{\text {tot }}$ for both models.

As observed for Jaffe's procedure, using the trade intensity procedure we obtain a positive R\&D competitive effect in the period before the beginning of the crisis (2002-2006) and a statistically negative effect for the period after the beginning of the crisis (2007-2010). Thus, we can conclude that our empirical findings are robust.

\section{Policy Implications and Conclusions}

This study provides additional insights into the relationship between competition and innovation through technological spillovers. In particular, the innovative contribution to the existing literature is twofold. First, the focus is on the identification of potential effects of the financial crisis on R\&D competition. For this purpose, we perform our analysis with reference to two different periods, one before the beginning of the crisis (2002-2006) and one after it (2007-2010). Second, the competition effect is explored by implementing an alternative empirical procedure based on trade intensity between sectors derived from input-output matrix data (Timmer et al., 2015).

We implement an analysis on 879 worldwide R\&D intensive firms. In order to identify the relatedness among firms in our sample, we follow two approaches: one based on Jaffe procedure (1986) relative to patents; one based on trade intensity between sectors using input-output matrix data (Timmer et al., 2015), which assumes that the more industry $i$ acquires from and sells to industry $j$, the more it may be affected by industry $j$.

The results obtained from the empirical analysis find close complementarity between physical capital and the firm's own R\&D expenditures. In particular, a significant positive impact of the firm's physical capital on its own investments in innovation is detected. When we consider the effects of technological spillovers on R\&D investment, the results show a significant and positive impact of $R \& D$ spillovers on competitive interactions in the period before the beginning of the crisis. This result is in line with the related literature (Capron and Cincera, 2001). However, as far as the period after the crisis is concerned, the effect of technological spillovers on strategic interactions becomes negative. These outcomes are robust with respect to the procedure employed in the estimation method. In light of these findings, it would be interesting in future research to investigate whether this negative effect is related to the different impact of the crisis on industrial sectors or also to the financial constraints of firms.

This study suffers from some limitations that could be addressed in further research. First, the panel data used covers a too short period, preventing analysis of a dynamic model. Second, the limited size of the sample in some sectors does not permit a sectoral analysis. Third, it would be relevant to examine the technological gap between the different geographical areas, focusing attention on the absorptive capacity variable (Cohen \& Levinthal, 1989).

Moreover, an important role may be also played by the public sector: public incentives favoring innovation can either be directed toward supporting the already existing R\&D infrastructures or toward stabilizing investments in innovation during recession periods.

\section{References}

Aldieri, L., \& Vinci, C. P. (2015). Knowledge migration: A cross-national analysis. De Economist, http://dx.doi.org/10.1007/s10645-015-9269-5

Aldieri, L., \& Vinci, C. P. (2016). Technological spillovers through a patent citation analysis, International Journal of Innovation Management, 20(2), http://dx.doi.org/10.1142/S1363919616500286 
Aldieri, L., \& Vinci, C. P. (2017). The Role of Technology Spillovers in the process of Water Pollution Abatement for Large International Firms, Sustainability, 9(5), 868. http://dx.doi.org/10.3390/su9050868

Archibugi, D., Filippetti, A., \& Frenz, M. (2013a). The impact of the economic crisis on innovation: Evidence from Europe. Technological Forecasting and Social Change, 80(7), 1247-1260 http://dx.doi.org/10.1016/j.techfore.2013.05.005

Archibugi, D., Filippetti, A., \& Frenz, M. (2013b). Economic crisis and innovation: Is destruction prevailing over accumulation? Research Policy, 42(2), 303-314 http://dx.doi.org/10.1016/j.respol.2012.07.002

Audretsch, D. B., \& Feldman, M. P. (1996). R\&D spillovers and the geography of innovation and production. American Economic Review, 86, 630-640

Blundell, R., Griffith, R. and Van Reenen, J. (1999). Market share, market value and innovation in a panel of British manufacturing firms. Review of Economic Studies, 66, 529-554.

Capron, H. (1994). Technological competition and strategy of firms inside the triad, in Khalil T. and Bayraktar B., (eds.), Management of Technology IV, The Creation Wealth, Industrial Engineering and Management Press, Nordcross.

Capron, H., \& Cincera, M. (2001). Technological competition, economic performance and strategic behavior of international firms. Brussels Economic Review, 169(169), 33-62.

Carboni, O. A. (2013). Investment in information and communication technologies (ICT): The role of geographic distance and industry proximity. The Review of Regional Studies, 43, 191-212.

Cohen, W. M., \& Levinthal, D. A. (1989). Innovation and learning: The two faces of R\&D. The Economic Journal, 99, 569-596.

European Commission. (2011). The 2011 EU Industrial R\&D Investment Scoreboard. JRC Scientific and Technical Research series. Retrieved from http://iri.jrc.ec.europa.eu/scoreboard.html

Filippetti, A., \& Archibugi, D. (2011). Innovation in times of crisis: National systems of innovation, structure, and demand. Research Policy, 40(2), 179-192. http://dx.doi.org/10.1016/j.respol.2010.09.001

Griliches, Z. (1979). Issues in assessing the contribution of R\&D to productivity growth. Bell Journal of Economics, 10, 92-116, http://dx.doi.org/10.2307/3003321

Jaffe, A. B. (1986). Technological opportunity and spillovers of R\&D: Evidence from firms' patents, profits and market value. American Economic Review, 76, 984-1001.

Morrison, P. C. J., \& Siegel, D. S. (1999). Scale economies and industry agglomeration externalities: A dynamic cost function approach. American Economic Review, 89, 272-290.

Nickell, S. (1996). Competition and corporate performance. Journal of Political Economy, 104, 724-746.

Paunov, C. (2012). The global crisis and firms' investments in innovation. Research Policy, 41(1), 24-35 http://dx.doi.org/10.1016/j.respol.2011.07.007

Peri, G. (2005). Determinants of knowledge flows and their effect on innovation. Review of Economics and Statistics, 87, 308-322, http://dx.doi.org/10.1162/0034653053970258

Scherer, F. M. (1967). Market structure and the employment of scientists and engineers. American Economic Review, 57(2), 524-531.

Scherer, F. M. (1992). International High- Technology Competition. Cambridge: Harvard University Press.

Scherer, F. M., \& Huh, K. (1992). R\&D reactions to high-technology import competition. Review of Economics and Statistics, 74(2), 202-212.

Timmer, M. P., Dietzenbacher, E., Los, B., Stehrer, R., \& de Vries, G. J. (2015). An illustrated user guide to the World Input-Output Database: The case of global automotive production. Review of International Economics, 23, 575-605. http://dx.doi.org/10.1111/roie.12178

\section{Notes}

Note 1 . As there are 879 firms, this results in 386,760 proximity measures.

Note 2. The total number of patents applied for by these firms was 922,673 over the period 2002-2010. 


\section{Copyrights}

Copyright for this article is retained by the author(s), with first publication rights granted to the journal.

This is an open-access article distributed under the terms and conditions of the Creative Commons Attribution license (http://creativecommons.org/licenses/by/4.0/). 